\title{
Study on Constructing Educational Practice Bases for Normal Universities
}

\author{
Ziqiang Luo \\ College of Information Science and Technology \\ Hainan Normal University \\ Haikou, China \\ 306003057@qq.com \\ Junkuo Cao \\ College of Information Science and Technology \\ Hainan Normal University \\ Haikou, China \\ jkcao@qq.com
}

\author{
Peng Cao \\ Dept. of Mathematics and Physics \\ Qiongtai Teachers College \\ Haikou, China \\ lanyuan97@126.com*Corresponding Author \\ Yu Zhang \\ College of Information Science and Technology \\ Hainan Normal University \\ Haikou, China \\ 344248003@qq.com
}

\begin{abstract}
There are quite a few matters in educational practice for normal universities, such as severely ignored construction of educational bases, monotonous patterns, shortage of educational funds, too narrow orientation of educational practice. Education practice is an important content of the education teaching activities for normal universities. As far as normal universities are concerned, educational practice bases play an important role to improve students' comprehensive quality, and cultivate students' practical ability and creative thinking. From the aspects of the significance, ideas, content and control measures, this essay tries to illustrate how to build effective educational practice bases.
\end{abstract}

Keywords-normal university; educational practice base; practical teaching; cooperation

\section{INTRODUCTION}

Practical teaching is an important platform to strengthen professional knowledge education, enhance the students' perceptual knowledge, improve the comprehensive quality of students, and cultivate the students' practical ability and innovative ability [1].

Educational probation and internship are two important organization parts of practice teaching. Probation puts emphasis on observation learning, but internship focuses on practice exercise. To achieve these two ways, students can't be an armchair strategist, educational practice bases should be established.

Knowledge comes from practice, ability comes from practice, and quality is more need to develop in practice. Practical teaching is an important link in training high-quality practical talents, and the construction of practical bases is the important guarantee of achieving this goal [2].

For a long period, normal universities have been plagued by the hard problem of practice. On account of the limitation of conditions, primary and secondary schools are reluctant to receive normal students. Due to various reasons, normal universities are lack of regular communication and in-depth exchanges with primary and secondary schools. It is not conducive to normal universities to cultivate new talents that suit the development of basic education, and goes against the improvement of primary and secondary school education quality.

The paper is constructed as follows: Section II introduces the significance of constructing educational practice bases for normal universities. Section III presents the ideas of constructing educational practice bases for normal universities: to achieve mutual benefit and win-win. Section IV and Section $\mathrm{V}$ put forward the content and measures of constructing educational practice bases for normal universities respectively.

\section{THE SIGNIFICANCE OF CONSTRUCTING EDUCATIONAL PRACTICE BASES FOR NORMAL UNIVERSITIES}

\section{A. Through the Construction of Educational Practice Base for Normal University, to Ensure Stable Practice Places for Normal Students}

Educational probation and internship are the only way which must be passed, as far as normal students are concerned. The nature and content of educational practice base determine its position as a main front in practical teaching. Qualified practice base is an important guarantee of successful educational practice [3]. If the schools are not relatively fixed for normal students to practice, it is difficult to form a stable practice guidance and the long-term cooperative relationship, to guarantee and improve the quality of educational practice.

In recent years, normal universities have established good cooperative relations with some primary and secondary schools, and established a number of relatively stable educational practice bases. To make further development of educational practice bases, it is necessary to rely on a few primary and 
secondary schools with good teaching conditions and high quality teaching as model practice bases.

\section{B. Through the Construction of the Educational Practice Bases for Normal Universities, to Promote the Level of Teaching and Scientific Research}

Normal university teachers have systematic teaching theory, but are short of practical experience. There are two main ways that university teachers understand the education situation of primary and secondary schools. Firstly, university teachers go to primary and secondary schools to guide students practice and internship. Secondly, the model lessons or the criticism lessons given by the famous teachers in primary and secondary schools are another way. Normal university teachers cannot get in-depth understanding of the classroom teaching of primary and secondary schools, and the teaching materials are grasped insufficiently. This results in the lack of targeted practical teaching case in teaching method lessons, although normal university teachers have a surplus of theoretical teaching. We have no shortage of famous teachers' teaching cases, but most of them are "acting classes". These kinds of "acting classes" are carefully polished after several rounds of preparation, high quality courseware and teaching aids, trial teaching, assessment reflection and modification.

But after graduated students entering primary and secondary schools, in addition to competition teaching, most of the lessons are actual. It is the most practical things that cannot be learned from famous teachers' teaching cases, when graduated students are treated like new kids on the block. What normal students' need to learn in teaching method lessons is how to teach in primary and secondary school in reality.

There is an urgent need to fully understand the actual classroom of primary and secondary schools with the help of educational practice bases. Theoretically, we should timely and accurate understand the reform developments of primary and secondary schools, understand the amendments of the new curriculum and the use of new teaching materials, and learn about new teaching strategies. In practice, we should enter into primary and secondary school classroom continually and deeply, collect and organize vivid teaching cases, learn how to control classroom discipline and implement class teaching strategies, and study children's mental dynamics, personality characteristics, learning habits and so on.

Through the combination of such theoretical and practical approach, not only the level of teaching method lessons can be further improved in normal universities, but also students' teaching skills can be promoted.

Practical teaching attached to the theoretical teaching in the traditional education mode has been extended to the modern education mode in the relatively independent system [4].

\section{Normal Universities Can Reserve Teachers for the Educational Practice Bases}

Naturally, primary and secondary schools need to introduce a number of teachers every year. Normal universities can reserve teachers for the educational practice bases. Because students carry out probation and internship in practice bases, can feel good teaching conditions atmosphere of practice bases, graduates will be able to choose the educational practice base for employment and schools can also enroll only those who are outstanding for the development of their own reserves of fresh blood.

\section{Normal Universities Can Promote Teachers' Overall Scientific Research Level for the Educational Practice Bases}

If we say that the educational practice base is the parade ground for students, also is a natural laboratory for teachers [4]. Normal universities can support the further development of scientific research and teacher training for education practice bases with a strong faculty, a higher level of scientific research, and the strong academic atmosphere.

\section{The IdEAS OF CONSTRUCTING EdUCATIONAL PRACTICE BASES FOR NORMAL UNIVERSITIES: TO ACHIEVE MUTUAL BENEFIT AND WIN-WIN}

The construction of educational practice bases should follow the principle of quality, representative, nearby and voluntary [3]. Normal universities must establish and perfect high standard, standardization, multi-function educational practice bases as soon as possible [5].

\section{A. The Interests of Normal Universities}

1. Normal students have stable and high quality educational practice places. The students can carry out a series of complete practical activities in the educational practice bases, such as probation, internship, professional skill training and the second classroom activities.

2. Normal students have the reserved choice of employment in the future.

3. Improve the talent training level of normal professional.

4. Improve the level of teaching method courses.

5. Accumulate of vivid first-hand information and materials, and thus increase the gold content of the primary and secondary educational project.

6. Promote the growth of the double-qualified teachers. Normal universities can regularly send young teachers to the educational practice bases, to obtain a comprehensive understanding of the law of the primary and secondary education.

\section{B. The Interests of Educational Practice Bases}

1. Recruit outstanding normal graduates every year at priority.

\section{Send teachers to normal universities for free training.}

3. Share abundant resources in normal universities' library.

4. Get help and guidance from normal universities' teachers, improve teachers' teaching level.

5. Obtain scientific research guidance from normal universities' teachers, enhance the overall scientific research 
level of the school. Scientific research guide includes writing teaching papers or research papers, and research project application.

6. Submit papers to internal publications in normal universities, improve teachers' enthusiasm and a sense of achievement.

\section{THE CONTENT OF CONSTRUCTING EDUCATIONAL PRACTICE BASES FOR NORMAL UNIVERSITIES}

\section{A. The Construction of Professional Teaching Team in Normal Universities.}

By sending regularly young teachers to educational practice bases, normal universities can obtain a comprehensive understanding of the law of the primary and secondary education, and further strengthen the development of doublequalified teacher team. By means of reinforcing cooperation with educational practice bases, the teacher team' structure will be reasonable and emerge as professional advantages, including the ability of practice teaching and the scientific research and development services.

\section{B. Strengthen the Construction of Primary and Secondary School Teaching Method Curriculum}

In the context of collaboration development, normal universities strengthen the cooperation with primary and secondary schools in the aspect of teaching practice curriculums, and we should organize university and primary and secondary school teachers to write teaching method textbooks when internal and external conditions are all mature.

\section{Improve Educational Practice Ability of Normal School Students.}

Normal university students should carry out practice activities with primary and secondary school teachers frequently. In practical terms, students observe the teaching activities of the guidance teachers, and give assistance once they can help; understand the process of how the guidance teachers prepare lessons, give lessons, visit and discuss the class; understand the basic knowledge and ability requirements; carry out normal skill training, simulation teaching activities, reflect with the guidance teachers after class. Lesson observation and evaluation among teachers is an effective way to communicate, learn from each other and enhance teaching art. This pattern of activity focuses on communication and cooperation, and emphasizes the application and deepens of the educational teaching theory learned. It is an innovation of practical teaching mode, and is a good attempt to train teachers, thus facilitate the achievement of students from knowledge to capacity-oriented and application-oriented.

\section{The Measures of Constructing Educational PRACTICE BASES FOR NORMAL UNIVERSITIES}

\section{A. Set Up the Leading Group of the Educational Practice Bases}

Both major school leaders are in charge of the leading group for the educational practice base, and the responsible and professional teachers are select as members.

\section{B. Put Forward Clearly Responsibilities and Tasks of the Bilateral Cooperation}

1) The responsibilities and duties of the normal universities

a) Arrange students to educational practice bases according to a systematic plan.

b) Formulate corresponding management system, strengthen the ideological and political work, discipline, safety education, etc.

c) Assign teachers with strong sense of responsibility and practical experience to guide practice.

d) Give full support and help to the educational practice bases taking advantage of the teaching and scientific research resources.

e) Arrange regularly for experts, professors, to educational practice bases for academic report or seminar.

2) The responsibilities and duties of the educational practice bases

a) Formulate corresponding management system and practice training instruction.

b) Receive normal students to carry out extracurricular counselling, education teaching research, practice activities.

c) Arrange for teachers with high professional skill level and strong professional dedication spirit as guidance teachers.

d) Provide good teaching and living environment for normal students.

e) Make trainees or interns evaluation, assist partner schools to accomplish practical teaching tasks.

f) Provide excellent teachers to exchange experience and outstanding teacher of the class for the students.

g) Accept one to two young university teachers on secondment for getting experience.

\section{ACKNOWLEDGMENT}

This work is supported by grants of National Nature and Science Foundation of China (No.61463012, No.61462025, No.61562024, No.61363032, No.6126207), Natural Science Foundation of Hainan Province (No.614233, No.114013, No.613161, No.613162), Qiongtai Teachers College Scientific Research Project (No.qtky201304). 


\section{REFERENCES}

[1] S. Ming, "Some reflections on the constrcution of the educational practice bases in the higher normal universities," Yinshan Academic Journal, vol. 20, pp. 107-109, Sep., 2006, In Chinese.

[2] Z. Guoxiang, "On the construction of preschool education professional campuse practice bases," Studies in Preschool Education, vol. 228, pp. 64-66, Dec., 2008, In Chinese.

[3] J. Jiafa, "Practice and thinking of constructing educational practice bases for normal university," China Higher Education Research, vol. 5, pp. 6465, May, 2005, In Chinese.

[4] C. Zhongpin and Z.Chuanjian, "The explore of the co-construction of higher normal education practice bases," Studies in Preschool Education, vol. 23, pp. 47-49, June, 2003, In Chinese.
[5] H. Mingbao, "Strengthen the construction of quality education practice bases, improve the students' innovation and practical ability,'Teacher Education Research, vol. 13, pp. 44-47, Apr., 2001, In Chinese.

[6] H. Tingmei, L. Guirong, "Practice and enlightenment of the construction of education practice base for European and American students in colleges and universities,"World Education Information, vol. 13, pp. 4447, June, 2001, In Chinese.

[7] C. Lixian, "The integration of the construction of teachers education practice bases and rural primary and secondary school-based training," China Adult Education, vol. 3, pp. 10-11, Apr., 2008, In Chinese.

[8] C. Faming, "Speculation and suggestions on patterns and construction of bases for practical education," Journal of Chongqing Normal University (Philosophy and Social Sciences Edition), vol. 4, pp. 106-110, Apr., 2015, In Chinese. 